ROCZNIKI HUMANISTYCZNE

Tom LXIX, zeszyt 2 - 2021

DOI: https://doi.org/10.18290/rh21692-2

\title{
DARIUSZ ROLNIK
}

\section{IDEA PAŃSTWA WOLNEGO, SUWERENNEGO I NIEPODLEGEEGO - FENOMEN PRZEMIAN CZASÓW SEJMU CZTEROLETNIEGO?}

Często w ocenach historiografii polskiej pojawiał się - tu wskazany w uproszczeniu - model myślenia sugerujący, że w okresie Sejmu Wielkiego dokonała się gwałtowna przemiana czy wręcz rewolucja w sposobie myślenia o Rzeczypospolitej ${ }^{1}$, której wynikiem miało być dążenie większości szlachty do reform i ugruntowania wskazanych w temacie trzech atrybutów Rzeczypospolitej, jakby jej trzech fundamentów: państwa wolnego, suwerennego i niepodległego ${ }^{2}$, a co wyrażać się miało w uchwaleniu Konstytucji

Dr hab. DARIUSz RoLNIK - Instytut Historii, Wydział Humanistyczny Uniwersytetu Śląskiego w Katowicach; e-mail: dariusz.rolnik@us.edu.pl; ORCID: https://orcid.org/0000-0002-7649-3142.

${ }^{1}$ Por. wymowa np. A.F. GRABSKI, Myśl historyczna polskiego oświecenia (Warszawa: Państwowe Wydawnictwo Naukowe, 1976), 214-215; K. BARTKIEwICZ, Obraz dziejów ojczystych w świadomości historycznej w Polsce doby oświecenia (Poznań: Państwowe Wydawnictwo Naukowe, 1979), 238-239, 246-247.

${ }^{2}$ Zwróćmy uwagę na definicje tych pojęć. Suwerenność - Jean Bodin, 1576 - zdolność do samodzielnego, niezależnego od innych podmiotów sprawowania władzy nad określoną grupą ludzi i terytorium. Państwo posiadające osobowość prawną. Niepodległość - niezależność państwa od formalnego i nieformalnego wpływu innych państw-jednostek politycznych. Wolność to m.in. prawa obywateli określone przez porządek prawny danego kraju i prawo do wyznawania swoich poglądów. Por. H. PelcowA, „Wolność i niepodległość w systemie wartości mieszkańców wsi”, Rozprawy Komisji Językowej ETN 60 (2014): 219-220, rozważania teoretyczne nad definicjami tych pojęć. O wolności por. U. AUGUSTYNIAK, „Granice wolności obywatela Rzeczypospolitej w XVI-XVII w. Jednostka wobec władzy, prawa i społeczeństwa”, w Wolność i jej granice. Polskie dylematy, red. J. Kloczkowski (Kraków: Ośrodek Myśli Politycznej, Wyższa Szkoła Europejska im. ks. J. Tischnera, 2007), 13-36; A. GRZEŚKOWIAK-KRWAWICZ, Regina libertas. Wolność w polskiej myśli politycznej XVIII wieku (Gdańsk: Wydawnictwo słowo/obraz terytoria, 2006), passim, szczególnie 295-329. 
3 maja. Takiej wymowie nie zamierzam tu jednoznacznie zaprzeczać, bo i trudno znaleźć w źródłach wiele głosów, które by w sposób otwarty spojrzenie to kwestionowały. Chciałbym natomiast rozważyć dwa zasadnicze elementy tytułowej konstrukcji - hipotezy. Pierwszy to czas, w którym dokonać się miała owa zasadnicza przemiana narodu szlacheckiego, a drugi to kwestia możliwości połączenia rzeczonych trzech atrybutów będących - czy mających być - podstawą funkcjonowania Rzeczypospolitej. Szczególnie chodzi o sposoby powiązania idei wolności z pragnieniami posiadania państwa suwerennego i niepodległego, w niniejszych rozważaniach te dwa ostatnie pojęcia będą traktowane jako tożsame, choć jest to pewne uproszczenie. Zasadniczą kwestią tu podejmowaną będzie wskazanie na problem i zarazem proces zmiany hierarchii wartości państwo - obywatel. Co było bądź kto był, czy stawał się podmiotem w myśleniu obywateli II połowy XVIII w.? Wydaje się, że wtedy stopniowo naród uznawał nad sobą priorytet Rzeczypospolitej. Zagadnienie to obserwowane będzie w zawężonym okresie czasów stanisławowskich do upadku państwa polsko-litewskiego, wówczas proces ten został przerwany, a i problem przestał istnieć, w każdym razie, znowu naród stał się najważniejszy. Przedstawiany tekst nie prezentuje ostatecznych rozwiązań. Jest jedynie wskazaniem jednej z widocznych dróg, którą podążały zmiany w myśleniu obywateli Rzeczypospolitej o swym państwie. Ten krótki artykuł bynajmniej nie wyczerpuje tematu, wskazuje tylko na jego istnienie i potencjalnie jego wagę dla dalszych badań nad dziejami stanisławowskimi.

Dyskusję o początku głębszej refleksji w Rzeczypospolitej nad stanem państwa polsko-litewskiego - w której wzmiankowane elementy stale się pojawiały, choć może nieco inaczej były pojmowane - proponuję rozpocząć symbolicznie od wystąpienia na sejmie konwokacyjnym 1764 r. Andrzeja Zamoyskiego. Ono nie tylko te wzmiankowane wyżej przemiany zapowiadało, lecz także przynajmniej częściowo rozpoczynało, a nade wszystko rozpropagowało. Ponadto trzeba zaznaczyć, o czym często się zapomina, że powstała mowa A. Zamoyskiego to odbicie pamięci zbiorowej współczesnych nie tyle o wolnościach szlacheckich, ile o pojęciu obywatelstwa w Rzeczypospolitej oraz przywilejach i obowiązkach z tym związanych. Mowa A. Zamoyskiego nie była pierwszą diagnozą stanu kraju, ale chyba pierwszą wygłoszoną publicznie w tak doniosłym momencie, a co było tego konsekwencją, po tymże kraju została „rozniesiona” i to wraz ze wskazaniem kierunku refleksji nad złym stanem państwa i sposobami jego naprawy ${ }^{3}$. Dotąd, owszem, myśliciele

\footnotetext{
${ }^{3}$ Por. B. LeŚnOdorski, „Mowy Andrzeja Zamoyskiego na konwokacji 1764”, w Księga pamiątkowa 150-lecia Archiwum Głównego Akt Dawnych (Warszawa: Państwowe Wydawnictwo
} 
czasów saskich pokroju Stanisława Konarskiego czy Stanisława Leszczyńskiego pisali o reformie, ich prace były drukowane, i to ich można nazwać „twórcami przełomu”, pozostawał mimo wszystko dość ograniczony, a krąg dyskutantów sprowadzał się zasadniczo do ścisłych elit szlacheckich. To zmieniło się dosyć szybko w początkach panowania Stanisława Augusta, dyskusja nad pomysłami reform czasów saskich zatoczyła dużo szersze kręgi.

Reformy zapowiadane przez A. Zamoyskiego bardzo szybko stały się przedmiotem publicznej debaty, i to na dalekiej prowincji i na sejmikach o drugorzędnym znaczeniu. Wiadomo, że dyskutowano o nich w 1765 r. na sejmiku w Mińsku. Rzecz jasna nie wiemy o wszystkich szczegółach dysputy oraz tego, jak głęboko sięgała refleksja, ale już sam fakt jest wart podkreślenia. Na sejmiku w Mińsku niektóre punkty programu A. Zamoyskiego, a szerzej „Familii”, zostały oddane pod głosowanie i jakkolwiek pełnymi danymi nie dysponujemy, to okazuje się, że na sejmiku wojewódzkim w Mińsku zostały one przyjęte bez większego sprzeciwu, a on sam odbył się już według nowych reguł ${ }^{5}$. Sejmik był tak liczny, że po pierwszym dniu następnego - 5 lutego 1765 r. - obrady musiano przenieść z izby zamkowej do kościoła dominikanów mińskich. Tam Ignacy Iwanowski, starosta miński, i Michał Żyżemski złożyli przysięgę na konstytucje sejmu koronacyjnego ${ }^{6}$. Dalszy ciąg sejmiku nie wyróżniał się niczym szczególnym, biorąc pod uwagę kwestie najistotniejsze w tym wywodzie. Można jedynie zwrócić uwagę na stale obecną mimo wszystko zakorzenioną w świadomości szlachty - ideę jedności, tę widać przy elekcji na podkomorzego mińskiego M. Żyżemskiego i chorążego mińskiego Floriana Bykowskiego, którzy zostali wybrani za jednomyślną zgodą ogółu ${ }^{7}$. Oczywiście, zmiany w myśleniu o sprawach zasadniczych dla państwa, dla narodu nie następują zazwyczaj gwałtownie - rewolucje również są etapem dojrzewania myśli - co także pokazał opisywany sejmik. Na nim przy wyborze sędziego ziemskiego ujawniły się dawne emocje, kandydatów

Naukowe, 1958), 383-386; J. MichALSKI, „Plan Czartoryskich naprawy Rzeczypospolitej”, w Studia Historyczne z XVIII i XIX wieku, t. I: Polityka i spoleczeństwo (Warszawa: Stentor, 2007), 13-24; J. MiCHALSKI, „O rzekomych i rzeczywistych pismach A. Zamoyskiego”, w Studia Historyczne z XVIII i XIX wieku, t. I, 135-136.

${ }^{4}$ Por. W. Bernacki, Myśl polityczna I Rzeczypospolitej (Kraków: Arcana, 2011), 301-328.

${ }_{5}^{5}$ Нацыянальны Гістарычны Архіў Беларусі, Мінск (dalej: NGAB), F 1727, op. 1, rkps 14, k. 64, Laudum sejmiku gromnicznego gospodarskiego i elekcyjnego ziemskiego województwa mińskiego, 12 II 1765.

${ }^{6} \mathrm{NGAB}, \mathrm{F} 1727$, op. 1, rkps 14, k. 64v.

${ }^{7}$ NGAB, F 1727, op. 1, rkps 14, k. 65v. 
było wielu, stąd i wiele stronnictw ${ }^{8}$, tu jednakowoż trudno stwierdzić, że kwestie ideologiczne decydowały w jakikolwiek sposób o sporach. Wskazany sejmik jako exemplum dyskusji publicznej toczonej na sejmikach tego czasu pokazuje, że kwestie zasadnicze były dyskutowane na prowincji na sejmikach, w których licznie uczestniczyła szlachta.

Następną ważną chwilą w tym procesie dostrzegania słabości własnych, a zarazem poszukiwania recept na poprawę kondycji państwa były konfederacje dysydenckie 1767 r., z ich finałem w postaci konfederacji radomskiej i sejmu delegacyjnego, za symbol której można uznać aresztowanie i zesłanie biskupów Kajetana Sołtyka, Jędrzeja Załuskiego oraz Wacława Rzewuskiego hetmana9 . To wówczas objawiła się wszem skala przewagi Rosji i jej ambasadorów w Rzeczypospolitej, a zarazem słabość tej ostatniej. Śmiem twierdzić, że na tej płaszczyźnie był to moment bardziej znaczący niż elekcja Stanisława Augusta wsparta wojskiem moskiewskim, jej chyba nawet Jędrzej Kitowicz nie ocenił aż tak negatywnie, zaznaczał w każdym razie niezłośliwie, że spokój na niej by $1^{10}$. Takie narzucone elekcje, nie twierdzę, że uznawane były za normę, ale one nie dziwiły ogółu obywateli, były w pewnym sensie dla ogółu szlachty przewidywalne. Towarzyszący elekcji $1764 \mathrm{r}$. wewnętrzny konflikt, owszem, dzielił społeczeństwo szlacheckie, ale był w połowie XVIII w. także czymś naturalnym, wynikał przecież, jak się wydaje, bardziej $\mathrm{z}$ antagonizmów personalnych niż różnic ideologicznych, te coraz bardziej stawały się wtórne. Zauważmy, że S. Konarski swymi myślami reformatorskimi służył dwóm najważniejszym walczącym ze sobą stronnictwom wspomnianej „Familii” i stronnictwu „republikańskiemu”"11. Natomiast przywołane

\footnotetext{
${ }^{8}$ NGAB, F 1727, op. 1, rkps 14, k. 66-66v.

${ }^{9} \mathrm{O}$ sprawie tej mówili praktycznie wszyscy, informacje o porwaniu z negatywną oceną tego zdarzenia można znaleźć nawet $\mathrm{w}$ korespondencji osób nieinteresujących się polityką, por. np. Biblioteka Narodowa (dalej: BN), rkps 9050, t. 2, k. 147v, S. Świeykowski do brata L.M. Świeykowskiego, Dąbrówka pod Tarnowem 29 XII 1772. Wydaje się, że właśnie ona wpłynęła niezwykle mocno na jeszcze większe upolitycznienie narodu szlacheckiego i trwała w pamięci zbiorowej bardzo długo, o czym przypominała też sprawa oceny stanu psychicznego uwolnionego K. Sołtyka, por. np. Biblioteka Czartoryskich w Krakowie (dalej BCz), SD 17414, 1-3, Mowa JW. Gedeona Jeleńskiego [...] miana w Senacie. 22 X 1782; NGAB, F 1636, op. 1, rkps 123, k. 104, G. Jeleński do [B.] Wolbeka, Warszawa 16 XII 1782; Biblioteka Kórnicka PAN (dalej BK), rkps 1188, k. 3-4v, [L.M. Świeykowski] Mentita est iniquitas sibi [1792]. Por. W. KonOPCZYŃSKI, Konfederacja barska, t. I (Warszawa: Volumen, 1991), 32-33.

${ }^{10}$ J. Kitowicz, Pamiętniki czyli Historia polska, oprac. P. Matuszewska, kom. Z. Lewinówna (Warszawa: Państwowy Instytut Wydawniczy, 1971), 143-146.

${ }^{11}$ J. MichalSKI, „Konarski Hieronim (Stanisław)”, w Polski słownik biograficzny, t. XIII, red. E. Rostworowski (Wrocław-Warszawa-Kraków: Zakład Narodowy im. Ossolińskich, Wydawnictwo Polskiej Akademii Nauk, 1967-1968), 471-477.
} 
już porwanie senatorów w 1767 r. pokazało i uzmysłowiło właściwie całemu narodowi szlacheckiemu, jak głęboko ingeruje Rosja w sprawy Rzeczypospolitej. To zdarzenie de facto oznaczało, że Rosjanie wchodzą w świat dotąd, mimo wszystko, hermetyczny dla obcych. Wolna elekcja w istocie zawierała przynajmniej dozę aprobaty dla obcych wpływów, lecz tych zewnętrznych, wszak - z wątpliwościami - były one dla większości szlachty w tym czasie drugorzędne, teraz zostały dotknięte ich „małe ojczyzny”, zatem potencjalnie ich małe wybory polityczne. Z obecnością obcych się godzono, ale i nauczono żyć, przecież zawsze jednak była to obecność ciała obcego, która nie będzie stała, a tylko tymczasowa. Wspomniane wydarzenia i konstytucje sejmu delegacyjnego ten obraz w przekonaniu większości politycznego narodu Rzeczypospolitej zmieniły.

Reakcją bardzo naturalną na te zdarzenia była konfederacja barska. Jakkolwiek początkowo miała ona być w założeniu pomysłodawców tylko mechanizmem wstrzymującym prawomocność konstytucji sejmu delegacyjnego, z prawami kardynalnymi gwarantowanymi przez Rosję ${ }^{12}$, to jednak szybko zaczęła się rozwijać oddolnie ${ }^{13}$. Wbrew pozorom - chociaż konfederacja barska rywalizację wewnętrzną zaogniła i była kontynuacją rywalizacji wewnętrznej z roku 1764 - był to ideologicznie również pierwszy istotny krok w kierunku połączenia idei silnego państwa z myślą o takim, które wewnątrz jest wolnym, opartym na idei suwerenności narodu i pełnej niepodległości Rzeczypospolitej. O tym, że myśl ta nie jest chybiona - abstrahując tu od partykularyzmów i osobistych animozji ${ }^{14}$ - przekonują wątpliwości dwóch wewnętrznych stron konfliktu, „Familii” - stronnictwa królewskiego oraz obozu republikańskiego. W obu pojawiała się myśl de facto wspólnego działania dla Rzeczypospolitej to w pewnych okresach propozycje z jednej strony Stanisława Augusta, a z drugiej biskupa kamienieckiego Adama Krasińskiego ${ }^{15}$. W każdym razie wszyscy

\footnotetext{
${ }^{12}$ Por. KonOPCZYŃSKI, Konfederacja barska, t. I, 37; E. RostworowSKI, „Z dziejów genezy konfederacji barskiej. Związek wojskowy Pułaskiego a dworski projekt reformy kawalerii”, w $Z$ dziejów wojny $i$ polityki. Księga pamiątkowa ku uczczeniu siedemdziesiątej rocznicy urodzin Janusza Wolińskiego, red. K. Hanulak (Warszawa: Wojskowa Akademia Polityczna im. F. Dzierżyńskiego, Wydział Historyczno-Polityczny, 1964), 148.

${ }^{13}$ KonOPCZYŃSKI, Konfederacja barska, t. I, 71-84.

${ }^{14}$ Tych niestety sporo, por. KONOPCZYŃSKI, Konfederacja barska, t. I, np. 166-168, 216-217, 253-254, 286-287.

${ }^{15}$ Por. np. Z. ZIELIŃSKA, „Stanisław August wobec konfederacji i konfederatów barskich”, w Konfederacja barska, jej konteksty i tradycje, red. A. Buchmann, A. Danilczyk (Warszawa: Wydawnictwo DiG, 2010), 118, 121-122, 126. Warto zaznaczyć, że wśród elit dominowała postawa zachowawcza wobec konfederacji, owszem, sprzyjano jej, ale również zachowywano się lojalnie wobec Stanisława Augusta - przykładem wymownym takiej postawy jest S. Konarski,
} 
w Rzeczypospolitej potępiali „porwanie senatorów”"16, a później, już w czasie trwania konfederacji barskiej, po obu walczących stronach pojawiają się myśli porozumienia, których wspólnym mianownikiem był sprzeciw wobec pozycji Rosji w Rzeczypospolitej ${ }^{17}$. Kwestia reformy państwa polsko-litewskiego w tym czasie nie była eksponowana, jako mogąca budzić kontrowersje i pogłębiać rozłamy, wydaje się, że świadomie ją pomijano. Kwestie praw dysydentów i praw kardynalnych postrzeganych jako wola Rosji w istocie łączyć mogły przeciwników wewnątrz Rzeczypospolitej i prowadzić do jedności w wystąpieniu przeciw Rosji. To konstrukcja teoretyczna pomijająca aspekty personalne, przyznaję, że jest to jej słabość. Niemniej w czasie konfederacji barskiej pokazało się wyraźnie dążenie obu stron konfliktu wewnętrznego do podjęcia idei walki o utrzymanie suwerenności i niepodległości Rzeczypospolitej, która byłaby gwarantem jej wolności wewnętrznej.

Wbrew pozorom ta wolność wewnętrzna przynajmniej teoretycznie miała się, moim zdaniem, w Rzeczypospolitej bardzo dobrze, a mianowicie powszechnie uważano, że to naród jest źródłem prawodawstwa. Przekonanie to było podstawą zachowania republikańskiej wolności, a jednocześnie pozwalało myśleć o reformie Rzeczypospolitej. W istocie po obu stronach walczących w Rzeczypospolitej w czasie konfederacji barskiej pojawia się ten sam cel $^{18}$, chociaż w szczegółach, niestety, postrzegany nie w ten sam sposób. Warto być może i z tej perspektywy spojrzeć na stosunkowo szybkie i łatwe pogodzenie się Stanisława Augusta z konfederatami barskimi po ich przegranej i po pierwszym rozbiorze - chyba nie zawsze konformizm był cechą, która o tym decydowała. To nie tylko z jednej strony konformiści, a z drugiej król kupujący „beneficjami” senatorskimi przeciwników i tworzący grupę

por. Michalski, „Konarski Hieronim”, 471-477. Por. też A.M. STASIAK, Patriotyzm w myśli konfederatów barskich (Lublin: Towarzystwo Naukowe KUL, 2005), 125-157.

${ }^{16}$ Zdawano sobie z tego sprawę także w Rosji, stąd przypuszczalnie pomysł rady senatu potępienia gwałtów N. Repnina, por. ZIELIŃSKA, „Stanisław August wobec konfederacji”, 124.

${ }^{17}$ A co wyrażało się w przeświadczeniu: „,swobody wewnętrzne i niepodległość kraju to dwa aspekty tej samej wolności”, A. GRZEŚKOWIAK-KRWAwICZ, „Przyszłam do Polski z Lechem... Konfederaci barscy a polska tradycja wolności”, w Konfederacja barska, jej konteksty i tradycje, 241. Rosja była po prostu dla niej zagrożeniem i tak była postrzegana przez ogół politycznego narodu i króla, inna kwestia to sprawa wystąpienia przeciw niej i determinacji w trwaniu w oporze. Por. też J. Michalski, Schylek konfederacji barskiej (Wrocław: Zakład Narodowy im. Ossolińskich, 1970), 34. Idea ta wszak gubiła się często w błędnych ocenach sytuacji międzynarodowej, w jakiej znalazła się Rzeczypospolita, i wewnętrznej, nierzadko też prywatne animozje sprawiały, że o ideach zapominano. Taką diagnozę możemy postawić tak obozowi „królewskiemu”, jak i „barskiemu”, por. IBIDEM, 36-45, 48-49, także biskup Adam Krasiński pogubił się w meandrach politycznych.

${ }^{18}$ Por. np. ZIELIŃSKA, „Stanisław August wobec konfederacji”, 120-121, 126. 
nazywaną przez jego przeciwników „pieczeniarzami królewskimi”. To problem zdecydowanie bardziej złożony i dotąd dostatecznie niezbadany. Z pojedynczych analiz źródłowych wynika, że do znacznej części postaci godzących się ze Stanisławem Augustem po konfederacji barskiej należały osoby ideowe, a przynajmniej jako takie się przedstawiające ${ }^{19}$, taką też był, w pewnym momencie nieprzejednany wróg Stanisława Augusta, Karol Stanisław Radziwiłł ${ }^{20}$. Z drugiej strony Stanisław August reprezentował postawę „dobrego, sprawiedliwego" króla dążącego do dobra Rzeczypospolitej ${ }^{21}$, co ułatwiało porozumienie. Sądzę, że nie powinna dziwić liczba osób związanych z konfederacją barską w szeregach stronnictwa królewskiego po 1778 r., decydowała o tym bynajmniej nie tylko koniunktura polityczna, ale również ich przekonanie co do tego, że Rzeczypospolita - państwo to wartość sama w sobie, bez której wszelkie inne prerogatywy przypisane narodowi wolnemu mogą zostać zdezawuowane. Jakże często później - po upadku konfederacji barskiej - zdarzało się, że Stanisław August powierzał ludziom walczącym w niej - jeszcze parę lat wcześniej nieprzejednanym, jak się wydawało, swym wrogom - prowadzenie sejmików ${ }^{22}$. Teoretycznie mógł przecież szukać i promować tylko te osoby, które stały na uboczu tych zdarzeń czasów barskich. Teza, że czynił tak, starając się pozyskiwać dawnych przeciwników

\footnotetext{
${ }^{19}$ Przykładem takim mogą być np. późniejsi senatorowie Adam Chmara, Marcin Leonard Świeykowski czy Michał Walewski, por. D. RoLnIK, Adam Chmara (1721-1805) - ostatni wojewoda miński w świecie polityki czasów stanisławowskich i jego archiwum [w druku]; D. ROLNIK, Leonarda Marcina Świeykowskiego (1721-1793) ostatniego wojewody podolskiego życie codzienne i publiczne oraz jego myśli o Rzeczypospolitej (Katowice: Wydawnictwo Uniwersytetu Śląskiego, 2016), 370-378; H. ŻEREK-KLESZCZ, „Michał Walewski podkomorzy krakowski i wojewoda sieradzki i jego korespondencja z królem Stanisławem Augustem 1777-1787”, Rocznik Łódzki 48 (2001): 47-65. Por. też H. ŻEREK-KLESZCZ, „Nominacje senatorskie Stanisława Augusta Poniatowskiego w okresie Rady Nieustającej”, Przegląd Nauk Historycznych 5, nr 1 (2006): 209-233.

${ }^{20}$ Por. J. MichalSKI, „Radziwiłł Karol Stanisław”, w Polski stownik biograficzny, t. XXX, red. E. Rostworowski (Wrocław-Warszawa-Kraków-Gdańsk-Lódź: Zakład Narodowy im. Ossolińskich, Wydawnictwo Polskiej Akademii Nauk, 1987), 257-259. Por. też np. opinię o wojewodzie wileńskim, J.U. NiEMcewicz, Pamiętniki czasów moich, oprac. J. Dihm, t. I (Warszawa: Państwowy Instytut Wydawniczy, 1958), 300.

${ }^{21}$ Por. A.M. STASIAK, Teoria władzy monarszej czasów stanisławowskich. Studium idei (Lublin: Wydawnictwo KUL, 2013), szczególnie, 319-457. W te ramy starał się wizerunkowo wpisywać Stanisław August.

${ }^{22}$ Por. np. postawę Adama Moszczeńskiego: Pamiętnik do historyi polskiej w ostatnich latach panowania Augusta III i pierwszych Stanisława Poniatowskiego przez Adama Moszczy[e]ńskiego (Poznań: Księgarnia Jana Konstantego Żupańskiego, 1863), 157; E. RosTwOROwSKI, „Moszczeński Adam”, w Polski stownik biograficzny, t. XXII, red. E. Rostworowski, (Wrocław-WarszawaKraków-Gdańsk-Łódź: Zakład Narodowy im. Ossolińskich, Wydawnictwo Polskiej Akademii Nauk, 1977), 87; RoLNIK, Leonarda Marcina Świeykowskiego, 380-384.
} 
politycznych z czysto altruistycznych pobudek, jest nie do udowodnienia. Wydaje się, że chyba faktycznie chciał budować - oczywiście bez specjalnego narażania się na rozgłos i opozycję ambasadora moskiewskiego Ottona Stackelberga - stronnictwo złożone z osób, którym dobro Rzeczypospolitej leżało na sercu. Przykładem tego może być kariera kontrowersyjnego Adama Moszczeńskiego ${ }^{23}$.

Pierwszy rozbiór spina w całość i podsumowuje ten początkowy okres dojrzewania idei walki o suwerenną, niepodległą i wolną wewnątrz Rzeczpospolitą. Jakkolwiek by krytycznie nie spojrzeć na sejm rozbiorowy z lat 1772-1775, grabież majątków pojezuickich i prywatne kariery - wbrew pozorom nieliczne w skali państwa ${ }^{24}$ - to jednak wówczas doszło do pewnych pozytywnych zmian w państwie polsko-litewskim. Powstały fora, na których mogła toczyć się dyskusja o tym, jak w przyszłości ma czy może wyglądać Rzeczypospolita, co dla niej dobre, a co złe. Pierwszym takim forum była Komisja Edukacji Narodowej ${ }^{25}$, drugim natomiast Rada Nieustająca, traktowana zazwyczaj tylko jako forma rządu, tak też była najczęściej postrzegana przez współczesnych przynajmniej do 1788 r. Niemniej było to również forum ścierania się, owszem, frakcji politycznych, ale i pomysłów na naprawę Rzeczypospolitej. Świadczyć o tym może chociażby fakt, że w istocie wszyscy znaczniejsi politycy tamtych czasów ubiegali się o miejsce w niej, choć oczywiście różne były motywacje skłaniające ich do tego ${ }^{26}$.

Kolejnym elementem istotnym, przywołującym myśli o ojczyźnie, była kwestia pierwszego rozbioru - abstrahując od wystąpienia Tadeusza Rejtana na sejmie rozbiorowym ${ }^{27}$ - to ewidentna trauma całego narodu szlacheckiego, która w połączeniu z klęską konfederacji barskiej dawała grunt pod pozytywne myślenie o państwie. Rozpacz po pierwszym rozbiorze w źródłach nie

\footnotetext{
${ }^{23}$ RostworowsKi, „Moszczeński Adam”, 87-91.

${ }^{24}$ D. Dukwicz, Rosja wobec sejmu rozbiorowego warszawskiego (1772-1775) (Warszawa: Instytut Historii PAN, 2015), 133-145.

${ }^{25} \mathrm{~W}$ kontekście podejmowanego tematu istotne jest, że ludzie o różnych poglądach zasiadający w KEN-ie działali w miarę zgodnie, por. Ł. KuRDYBACHA, M. MiterA-DobrowolsKA, Komisja Edukacji Narodowej (Warszawa: Państwowe Wydawnictwo Naukowe, 1973), 50-51, 54-55.

${ }^{26}$ Por. np. zestawienie personalne składu Rady Nieustającej, A. CZAJA, Między tronem, buława a dworem petersburskim. Z dziejów Rady Nieustajacej 1786-1789 (Warszawa: Państwowe Wydawnictwo Naukowe, 1988), 77-95. Motywacja, by działać w niej przeciw królowi, a w obronie praw, jest dyskusyjna.

${ }^{27}$ Por. np. J. MichalsKi, „Rejtan i dylematy Polaków w dobie pierwszego rozbioru”, w idem, Studia Historyczne z XVIII i XIX wieku, t. I, 160-167, 176-177, 188-201, tu o złożoności problemu i szansach na odmowę ratyfikacji rozbiorów.
} 
jest aż tak bardzo widoczna ${ }^{28}$, ale nie ma wątpliwości, że to zdarzenie wpłynęło na sposób myślenia ówczesnych elit o relacji między wolnością w państwie a niepodległością czy suwerennością Rzeczypospolitej ${ }^{29}$. Refleksja musiała po tych doświadczeniach przyjść - taka była natura narodu szlacheckiego, w której jego państwo miało przecież od wieków istotną wartość. Okazywało się jednak, że dla jego podniesienia stare hasła odwołujące się do „Ojczyzny - Rzeczypospolitej” musiały nabrać nowej mocy. Aby to nastąpiło, problemy generujące słabość państwa polsko-litewskiego musiały wcześniej zostać dostrzeżone, przynajmniej przez większą część szlachty państwa polsko-litewskiego. I tak się powoli działo w następnych latach.

Być może mniej widoczny, ale równie ważny, jeżeli nie ważniejszy w rozwoju myśli o Rzeczypospolitej niż czas - symbolicznie - pierwszego rozbioru, był tzw. okres sejmów wolnych z lat 1778-1786, z przedłużeniem do lata 1788 r. Nie wyróżniły się one szczególnie jeżeli chodzi o dorobek ustawodawczy $^{30}$, ale każdy z nich pobudzał do dyskusji o wolności i jej granicach oraz o niepodległości, suwerenności, niezależności Rzeczypospolitej. Sejm 1780 r. na kanwie ataków na podskarbiego litewskiego Antoniego Tyzenhauza pokazywał krytyczny stosunek większości obywateli do działań pozaparlamentarnych tego ministra, co w efekcie skutkowało jego przegraną polityczną ${ }^{31}$. Również ten sejm, jakkolwiek odrzucający kodeks Andrzeja

${ }^{28}$ Wydaje się, że z różnych względów miano problem z jej okazywaniem, ale ona była, por. np. „Notatki generała J.L. z lat 1775-1778. Ze starego rękopisu zebrane przez J.I. Kraszewskiego”, Biblioteka Warszawska 2 (1854): 424; Krótki pamiętnik A. Hulewicza konfederata barskiego, w K. PUŁASKI, Szkice i poszukiwania historyczne. Serya trzecia (Kraków: Spółka Wydawnicza Polska, 1906), 387-388; Pamiętniki Józefa Kossakowskiego biskupa inflanckiego 1738-1788, wyd. A. Darowski (Warszawa: Księgarnia Gebethnera i Wolffa, 1891), 149. Por. też D. RolNiK, Portret szlachty czasów stanisławowskich, epoki kryzysu, odrodzenia i upadku Rzeczypospolitej w pamiętnikach polskich (Katowice: Wydawnictwo Uniwersytetu Śląskiego, 2009), 228-232.

${ }^{29}$ O czymś podobnym świadczy chociażby przypominanie „dawnych” granic czy „dawniej naszych krajów”, por. np. Lietuvos Mokslų Akademijos Vrublevskių Biblioteka, Vilnius, F 17, rkps, k. 6v, Dziennik podróży po Europie; [Franciszek Bukaty] Dyjariusz podróży z Polski do Anglij z opisaniem wszelkich obserwacyi $i$ ciekawości, które się mogły nadarzyć przejeżdżając przez różne miasta, w B. RoK, „Opis podróży przez Niemcy i Holandię do Londynu anonimowego szlachcica litewskiego z 1780 r.”, Śląski Kwartalnik Historyczny Sobótka 49, z. 3-4 (1994): 268-269; Pamiętniki Józefa Kossakowskiego, 149. Por. też np. RolnIK, Portret szlachty czasów stanisławowskich, 230-231.

${ }^{30}$ Por. R. ŁASZEWSKI, Sejm polski w latach 1764-1793. Studium historyczno-prawne (Warszawa-Poznań: Państwowe Wydawnictwo Naukowe, 1975), passim; J. MichALSKI, „Sejm polski w czasach panowania Stanisława Augusta", w Historia sejmu polskiego, red. J. Michalski, t. I (Warszawa: Państwowe Wydawnictwo Naukowe, 1984), 350-419; W. FILIPCZAK, Sejm 1778 roku (Warszawa: Semper, 2000), 7.

${ }^{31}$ Por. FILIPCZAK, Sejm 1778 roku, 140-141; A. KALENKIEwiCZÓwnA, „Rozkład partii Tyzenhauza na tle sejmików litewskich”, w Księga pamiątkowa Koła Historyków słuchaczy USB w Wilnie 
Zamoyskiego - razem z procesem jego tworzenia, dał asumpt do dyskusji nad definicją narodu i, szerzej, nad ustrojem państwa, wszak Kodeks Zamoyskiego był propozycją znacznej przebudowy kraju ${ }^{32}$. Do dyskusji nad kondycją Rzeczypospolitej skłaniały także następne sejmy. Casus biskupa krakowskiego Kajetana Sołtyka uznanego za szaleńca, dyskutowany na sejmie $1782 \mathrm{r.}^{33}$, a później sprawa otrucia księcia Adama Czartoryskiego przez Franciszka Ryxa, szerzej i trafniej nazywana ,aferą Dogrumowej”, która zdominowała obrady sejmu 1786 r. $^{34}$, były kolejnymi momentami, w których kwestie związane z problemem modelu funkcjonowania Rzeczypospolitej były podejmowane w dyskusjach. We wszystkich wskazanych przypadkach nie chodziło o finał owych konkretnych spraw, ale ich otoczkę. Dotykały one wątków ustrojowych, społecznych i politycznych, co istotne dyskutowano o nich na prowincji, może nie tyle zażarcie, ile czasami bardziej praktycznie, stopniowo uświadamiając sobie konieczność zmian systemowych. One najczęściej nie były artykułowane i werbalizowane (chociaż istniało przekonanie o ich konieczności, wręcz nieuchronności), a zarazem przygotowywały na nadchodzące - jeszcze nieskonkretyzowane - zmiany w państwie polsko-litewskim. Walka stronnictwa królewskiego z opozycją nazywaną bądź hetmańską, bądź republikańską była ostra, chociaż, na co trzeba zwrócić uwagę, prowadzona coraz częściej - mimo wszystko - nie na szable, lecz na argumenty, i to nie tyle polityczne, lecz takie, które definiowały dobrego obywatela, a te sprowadzały się do stworzenia katalogu cech, którymi miał się charakteryzować. $\mathrm{Z}$ nich w przedstawianym tekście najważniejszą była służba Ojczyźnie. Ta, ale również inne cechy dobrego obywatela stały się, czy dopiero stawały się normą dla wszystkich uczestników życia publicznego, za tym szło zbliżenie

(Wilno: Zrzeszenie Kół Naukowych Uniwersytetu Stefana Batorego, 1933), 121-155; S. KośCIAŁKOwsKI, Antoni Tyzenhauz, podskarbi nadworny litewski (Londyn: Wydawnictwo Społeczności Akademickiej Uniwersytetu Stefana Batorego w Londynie, 1971), t. I, 161-163; t. II, 328-338, 413-434; W. FILIPCZAK, Życie sejmikowe prowincji wielkopolskiej w latach 1780-1786 (Łódź: Wydawnictwo Uniwersytetu Łódzkiego, 2012), 40-46.

32 Por. K. AdolPhOwA, „Szlachta litewska wobec Zbioru Praw Andrzeja Zamoyskiego (w świetle litewskich instrukcji poselskich z lat 1776, 1778, 1780, 1782)", w Księga pamiatkowa Koła Historyków, 156-188; FILIPCZAK, Życie sejmikowe, 63-64.

${ }^{33}$ Por. K. RudNICKI, Biskup Kajetan Soltyk 1715-1788 (Kraków-Warszawa: W.L. Anczyc, 1906), 210-241; FILIPCZAK, Życie sejmikowe, 76-83.

${ }^{34}$ Por. A. DANILCZYK, W kręgu afery Dogrumowej. Sejm 1786 roku (Warszawa: Neriton, 2010), 177-182; FiliPCZAK, Życie sejmikowe, 134-140. Do sprawy podchodzono z dystansem, co dobrze pokazuje korespondencja Wincentego Gurskiego z L.M. Świeykowskim, por. np. Biblioteka Zakładu Narodowego im. Ossolińskich we Wrocławiu, rkps 1996, k. 114, 118, 127-128, 130-133, [W.] Gurski do L.M. Świeykowski, Warszawa 18 i 25 I 1785, 1, 8, 15 III 1785. Por. RolNIK, Leonarda Marcina Świeykowskiego, 425-427. 
frazeologii wystąpień obu rywalizujących ugrupowań. Ojczyzna - Rzeczypospolita w przekazie wszystkich występujących publicznie osób miała być niepodległa, suwerenna i - co równie ważne - silna. Kryteria doboru osób do funkcji publicznych przez zwalczające się strony były również wyraźnie zbieżne. Adam Czartoryski pisał do Kazimierza Zawiszy, by pozyskać jego wsparcie na sejmiku poselskim o jego „obywatelstwie powszechnego dobra gorliwością tchnącym”, tak by wybrać posłów „zdatnych” i „talentami znajomych" ${ }^{35}$. Takie same w wymowie słowa kierował do swoich stronników Michał Poniatowski, będący - przynajmniej w tym okresie - w opozycji politycznej do A. Czartoryskiego ${ }^{36}$. I za to samo, za poświęcenie dla ojczyzny i „wydźwignięcie kraju z upadku” w pewnym momencie, w 1789 r. dumny - chwalił Stanisława Szczęsnego Potockiego jeden z jego ekonomów ${ }^{37}$. Jakkolwiek konteksty i okoliczności tych wypowiedzi są różne, to brzmienie bardzo podobne, a wymowa jednoznaczna: w przestrzeni publicznej powinni funkcjonować tylko ci, którzy deklarują działania dla dobra Rzeczypospolitej. Znamienny w tym kontekście był proces Adama Ponińskiego na Sejmie Wielkim, czy kwestia przysiąg, że nie było się pensjonariuszem obcych mocarstw. Z satysfakcją pisał Adam Chmara, wojewoda miński, ,ja śmiało" z księciem kanclerzem litewskim Aleksandrem Sapiehą pójdę do przysięgi ${ }^{38}$.

Okazywało się, że czasami cel polityczny - np. reformy państwa - różnie nazywany, inaczej określany, faktycznie był bardzo podobny i okazywał się wspólny. Z tego wynikają spore problemy z określeniem grup zwolenników poszczególnych opcji politycznych zwalczających się na sejmach. Często okazywało się - co wręcz było regułą - że poza „prowadzącymi” stronnictwo królewskie czy mu przeciwnymi liderami opozycji reszta ich potencjalnych zwolenników była od nich w dużej mierze niezależna, myślała innymi kategoriami. W myśleniu - czasami błędnym - o swoim państwie stawali się oni niezależni, choć również na pewno kierowali się interesami partykularnymi, a nie zawsze podporządkowanymi stronnictwu królewskiemu czy możno-

\footnotetext{
${ }^{35}$ NGAB, F 694, op. 1, rkps 313, k. 6, Adam Czartoryski do Kazimierza Zawiszy, Słonim 29 I 1776.

${ }^{36}$ Archiwum Główne Akt Dawnych w Warszawie, Archiwum Ekonomiczne prymasa Poniatowskiego, rkps 121, k. 42, M. Poniatowski do M. Podoskiego, [Płock] 7 VII 1784. Por. też D. RoLNIK, „Sejmiki poselskie drugiej połowy panowania Stanisława Augusta (1778-1793). O czynnikach i motywacjach decydujących o wyborze posłów sejmowych”, w Po unii-sejmiki szlacheckie w Rzeczypospolitej XVI-XVIII wieku, red. H. Lulewicz, M. Wagner (Siedlce: Instytut Historii i Stosunków Międzynarodowych Uniwersytetu Przyrodniczo-Humanistycznego, 2013), 331-355.

${ }^{37}$ NGAB, F 694, op. 1, rkps 337, k. 27, NN do S. Sz. Potockiego, Brahiłów? 8 IV 1789.

${ }^{38}$ NGAB, F 1324, op. 1, rkps 43, k. 172, A. Chmara do żony [Marianny Chmarzyny], Warszawa 17 XII 1788.
} 
władczym partiom coraz bardziej słabnącej magnaterii. Wydaje się, że to jest najistotniejsza zmiana, która zaszła w czasach stanisławowskich. Mianowicie rywalizacja stronnictwa królewskiego z opozycją magnacką doprowadziła do wykształcenia się trzeciej siły, poniekąd niezależnej, która z jednej strony zauważyła, o co nie było trudno, słabość stronnictwa królewskiego uwikłanego we współpracę z dworem Katarzyny II, a z drugiej strony dostrzegła, że żadnej trwałej gwarancji nie dają dwory magnackie, które są wręcz bezsilne wobec przewagi moskiewskiej. Ten ostatni aspekt był być może mniej odczuwalny w centralnej i zachodniej Rzeczypospolitej, ale również i tam był dostrzegalny, choć na pewno nie tak boleśnie jak miało to miejsce na kresach wschodnich państwa polsko-litewskiego ${ }^{39}$.

Dojrzewanie narodu szlacheckiego do naprawy Rzeczypospolitej w duchu republikańskim, ale mającym na uwadze przede wszystkim państwo tego republikańskiego narodu - Rzeczpospolitą i jego siłę, wyraźnie widać w 1788 r. To, dla piszącego te słowa, wręcz ,jabłko Newtona”, ono dojrzewało, jak starano się wykazać w czasach stanisławowskich, i po prostu spadło pod wpływem promieni, czyli kłopotów Rosji i Katarzyny II, które pozwoliły narodowi szlacheckiemu w latach Sejmu Czteroletniego na w miarę swobodne wyartykułowanie swych pragnień. Zawierały się one w chęci utrzymania wolności obywatelskich, wolności szlacheckich i suwerenności - niepodległości silnej Rzeczypospolitej. Wydaje się, że celem większości zaangażowanej politycznie w czasach Sejmu Wielkiego szlachty państwa polsko-litewskiego było stworzenie organizmu państwowego będącego silnym na zewnątrz i wolnym, ale też rządnym, wewnątrz. To bardzo zdroworozsądkowa konstatacja, ale zdaje się, że to właśnie nią kierowali się obywatele, uchwalając 100-tysięczną armię ${ }^{40}$, a potem sami obciążając się ofiarą 10 grosza - od 300 lat szlachta te projekty konsekwentnie odrzucała, choć przecież stale takie były wysuwane ${ }^{41}$

${ }^{39}$ Abstrahując już od politycznych możliwości oddziaływania najmożniejszych rodów litewskich Sapiehów, Radziwiłłów czy Sanguszków, to i one musiały godzić się na furaże dla armii moskiewskiej i znosić narzucane przez jej dowódców obciążenia, por. np. Archiwum Narodowe w Krakowie, ASang., Teki arabskie, rkps 273/1, 505, [?] Stroynowski do H. Sanguszki, Babunow 7 XI 1786. Por. też RolniK, Leonarda Marcina Świeykowskiego, 288-297.

${ }^{40}$ Co równie istotne, to była armia chciana, „nasza”, por. D. RoLNIK, „Społeczeństwo szlacheckie Rzeczypospolitej a wojsko w czasie Sejmu Czteroletniego i w okresie rządów konfederacji targowickiej (1788-1793)", w Spoleczeństwo staropolskie. Seria nowa, t. IV, red. I.M. Dacka-Górzyńska, A. Karpiński, M. Nagielski (Warszawa: Wydawnictwo DiG, 2015), 309-334.

${ }^{41}$ NGAB, F 1324, op. 1, rkps 88, k. 54-55, Kopia listu JW. Sapiehy podkomorzego [podkanclerzy Michał Antoni] WKL na sejmiki, bdm. [1752-1760?]. [1752-1760?]. Kopia listu JW. Sapiehy podkomorzego [podkanclerzego Michała Antoniego] WKL na seymiki, bdm. Wzywał do aukcji wojska, do zaniechania waśni, bo tego oczekuje „ojczyzna matka nasza”, bowiem „Na- 
na Sejmie Czteroletnim. Nie wystąpił przeciw nim - a przynajmniej przeciwko samej idei - nikt. Mechanizm takiego myślenia był prosty: lepszy własny król z obowiązującymi uregulowaniami prawnymi albo ze wzmocnioną władzą niż dyktat carski lub innego sąsiada. Wolność obywatelska w czasach stanisławowskich nie była postrzegana już tylko jako „złote wolności”, liberum veto czy wolne elekcje, to były przeżytki minionej dawnej epoki. Kto pamiętał w 1788 r. liberum veto, a kto wolną elekcję? Minęło co najmniej jedno pokolenie, nie znaczy, że haseł tych nie pamiętano, ale traciły one i na znaczeniu, i na nośności. Obywatele coraz bardziej zdawali sobie sprawę, że nie one są źrenicami wolności szlacheckiej, natomiast wartością jest to, co daje prawo o współdecydowaniu o swoim państwie, czyli że moc tworzenia prawa należy do narodu. Ponadto wówczas było to najpewniej powszechne przekonanie, że aby w takim kształcie ich państwo istniało, musi być niepodległe od obcych nacisków i suwerenne w podejmowaniu decyzji o swoim bycie. Konstytucja 3 maja nie była rewolucją w myśli politycznej, ale co najwyżej w świadomości obywateli, którzy zaczęli inaczej traktować swoje państwo. Nie tyle Konstytucja 3 maja, ile cały Sejm Czteroletni $\mathrm{z}$ jego ustawodawstwem o podatkach i aukcji wojska o tym zaświadcza, to były powszechnie akceptowane narzędzia naprawy państwa polsko-litewskiego. Zasadnicze zręby tego państwa były w istocie znane społeczeństwu szlacheckiemu wcześniej, stąd akceptacja wręcz bezwarunkowa owych zmian, stąd także sprzeciw wobec zasady dziedziczności proponowanej w „referendum” listopadowym $1790 \mathrm{r}^{42}{ }^{4}$; podobnie również stosunkowo łatwa akceptacja tej zmiany ustrojowej na sejmikach lutowych $1792 \mathrm{r}^{43}$ Pierwsze - konsultowane reformy podatkowe i wojskowe otworzyły drogę do naprawy oraz wzmocnienia Rzeczypospolitej. Kolejna, likwidacja wolnej elekcji, nie była dla obywateli „pierwszorzędna”, ale trzeba zauważyć, że to właśnie była przysłowiowa ostatnia „złota wolność szlachecka”, co miało wpływ na nieco sentymentalny stosunek szlachty do jej potencjalnej likwidacji. Jednak przede

chyla się ojczyzna na bliski upadek”. Dalej pisał: „łatwo można znaleźć pieniądze na utrzymanie wojska, tylko trzeba chcieć je dać”. Por. o uchwaleniu podatku, R. BUTTERwick, Polska rewolucja a kościól katolicki 1788-1792 (Kraków: Arcana, 2012), 351-365.

${ }^{42}$ Por. Z. ZielińsKA, „O sukcesyi tronu w Polszcze” 1787-1790 (Warszawa: Wydawnictwo Naukowe PWN, 1991), 207-221; RoLNIK, Leonarda Marcina Świeykowskiego, 503-509. Por. też dyskusję na sejmikach lutowych, Z. ZIELIŃSKA, „Sejmiki 8 lutego 1790. Pierwsze referendum na temat dokonań sejmu", Wiek Oświecenia 9 (1993): 117-124.

${ }^{43}$ Por. wyniki sejmików lutowych w sprawie uznania Konstytucji 3 maja, sprzeciwu nie wyraził żaden, W. SzCZYGIELSKI, Referendum trzeciomajowe. Sejmiki lutowe 1792 roku (Łódź: Wydawnictwo Uniwersytetu Łódzkiego, 1994), 394-396. 
wszystkim, po listopadzie 1790 r., usunięcie wolnej elekcji z konstytucji podważało prawo narodu do stanowienia prawa ${ }^{44}$, to było sedno sporu, nie sama prawna konstrukcja, wiedziano jak wolna elekcja może być szkodliwa $^{45}$. Warto natomiast podkreślić, że ustawodawstwo sejmu 1788-1792 zmieniało definicję narodu. Odtąd już nie krew płynąca w żyłach decydowała o takiej kwalifikacji, ale przede wszystkim płacone podatki - one wskazują, kto jest obywatelem ${ }^{46}$. Przeciw tej zasadzie protestów $w$ istocie brak, upominano się co najwyżej o prawa do głosu szlachty gołoty, ale o to nikt nie chciał kruszyć kopii ${ }^{47}$. Również po przegranej wojnie w obronie ustawy majowej sugerowane wyżej myśli o reformie państwa i idee zmiany definicji obywatela bynajmniej nie były zupełnie odrzucane przez targowiczan ${ }^{48}$, zresztą większość z nich była akceptowana - chociaż może nie do końca wspierana - w czasie powstania kościuszkowskiego ${ }^{49}$.

Wydaje się, że warto zastanowić się nad trwaniem w Rzeczypospolitej idei państwa wolnego - jej obywatela i jego ojczyzny - oraz definicjami tych pojęć w świadomości obywateli II połowy XVIII w. Lata po upadku konfederacji barskiej wskazywać by mogły pozornie na zanik tych idei, to jednak tylko pozór. Idee dawnej Rzeczypospolitej z jej wolnościami szlacheckimi,

${ }^{44}$ Por. np. Rolnik, Leonarda Marcina Świeykowskiego, 517-518, 522, 526, 560.

${ }^{45}$ Por. np. R. LIS, W poszukiwaniu prawdziwej Rzeczypospolitej. Główne nurty myśli politycznej Sejmu Czteroletniego (Kraków: Akademia Ignatianum, Wydawnictwo WAM, 2015), 300-303; R. ButTerwick, Polska rewolucja, 712-714.

${ }^{46}$ Świadczy o tym dobitnie wprowadzany próg podatkowy, którego spełnienie sprawiało, że było się dopuszczonym do czynnego prawa wyborczego, por. Sejmiki. Prawo uchwalone dnia 24 marca 1791, 37-39 [reprint, Kórnik: Polska Akademia Nauk, Biblioteka Kórnicka, 1985]. O ideologicznym podłożu i mechanizmach procesu por. np. T. ŁEPKOWSKI, Polska - narodziny nowoczesnego narodu 1764-1870 (Warszawa: Państwowe Wydawnictwo Naukowe, 1967), 216-232; J. BuRSZTA, „Lud naród - kultura. Z początków ludoznawstwa”, w Naród. Kultura. Osobowość. Księga poświęcona Profesorowi Józefowi Chałasińskiemu (Wrocław: Zakład Narodowy im. Ossolińskich, 1983), 39-46.

47 Tak można interpretować chociażby projekty targowiczan, którzy w większości nie zamierzali przywracać dawnych praw gołocie, por. BK, rkps 1188, k. 6v-7, [L.M. Świeykowski], Myśli obywatelskie nad ustanowieniem formy rządu republikańskiego; RoLNIK, Leonarda Marcina Świeykowskiego, 601, 606-607.

${ }^{48}$ Por. RolNIK, Leonarda Marcina Świeykowskiego, 603-604, 606. Por. S. CHELIŃSKI, Organizacja państwa polskiego wedtug ustaw Sejmu Grodzieńskiego z r. 1793 (Warszawa, 1918), 19; J. WĄSICKI, Konfederacja targowicka i ostatni sejm Rzeczypospolitej z 1793 roku (studium historyczno-prawne) (Poznań: Poznańskie Towarzystwo Przyjaciół Nauk, 1952), 94-95, 97-98, tu wskazano na elementy i zapisy podobne do brzmienia ustawodawstwa Sejmu Wielkiego.

${ }^{49}$ Por. np. A. GrZeŚKOWIAK-KRWAWICZ, „Wolność w propagandzie powstania kościuszkowskiego", w Kościuszko - powstanie 1794 r. - tradycja. Materiały z sesji naukowej w 200-lecie powstania kościuszkowskiego, 15-16 kwietnia 1994 r., red. J. Kowecki (Warszawa: Biblioteka Narodowa, 1997), 45; A. ZAHORSKI, „Powstanie kościuszkowskie 1794”, w Trzy powstania narodowe. Kościuszkowskie, listopadowe, styczniowe, red. W. Zajewski (Warszawa: Książka i Wiedza, 2000), 30. 
ale również z obowiązkami wobec niej, trwały ciągle w czasach stanisławowskich. Wszak coraz bardziej widoczna stawała się dysproporcja między „złotymi wolnościami” a faktyczną wolnością decydowania o swym państwie, czyli jego suwerennością i niepodległością, a przecież temu miały pierwotnie służyć liberum veto i wolna elekcja. Okazały się one nieskuteczne, czego naocznym dowodem był obraz i stan Rzeczypospolitej uzależnionej od sąsiadów, co widziano z każdego miejsca w państwie polsko-litewskim. Panowanie Stanisława Augusta to czas stopniowego i bolesnego dojrzewania do zmian, do reform społecznych, politycznych i ustrojowych. Powszechne dostrzeganie słabości doprowadziło do sytuacji, w której większość godziła się na istotne zmiany, takie, które ratować miały ich państwo. To musiało przy pierwszej nadarzającej się okazji - doprowadzić do „rewolucji” 3 maja. Pojęcie rewolucja znalazło się tu w cudzysłowie dlatego, że Konstytucja 3 maja, jakkolwiek była uchwalona w rewolucyjny sposób, to jej treści nie były żadnym zaskoczeniem, co najwyżej tylko mógł być zaskoczeniem dzień 3 maja. Reformy Sejmu Wielkiego i jego ustawa zasadnicza z 3 maja $1791 \mathrm{r}$. wynikały z potencjału i mimo wszystko z siły intelektualnej tkwiącej w elitach narodu szlacheckiego panowania stanisławowskiego. Dodajmy, że zarówno ten potencjał, jak i siły intelektualne wzrastały sukcesywnie w czasie panowania Stanisława Augusta w ciągłych sporach politycznych, ale również co czasami jest mniej dostrzegalne - intelektualnych i światopoglądowych.

\section{BIBLIOGRAFIA}

\section{ŹRÓDŁA RĘKOPIŚMIENNE}

Archiwum Główne Akt Dawnych w Warszawie

Archiwum Ekonomiczne prymasa Poniatowskiego, rkps 121, k. 42. Bruliony listów M. Poniatowskiego.

Archiwum Narodowe w Krakowie Archiwum Sanguszków, Teki arabskie, rkps 273/1. Korespondencja Sanguszków.

Biblioteka Książąt Czartoryskich w Krakowie. SD 17414, s. 1-3. Mowa JW. Gedeona Jeleńskiego [...] miana w Senacie, 22 X 1782.

Biblioteka Kórnicka PAN

Rkps 1188. Papiery L.M. Świeykowskiego.

Biblioteka Narodowa

Rkps 9050, t. 2. Korespondencja Świeykowskich.

Biblioteka Zakładu Narodowego im. Ossolińskich we Wrocławiu Rkps 1996. Listy Wincentego Gurskiego.

Lietuvos Mokslų Akademijos Vrublevskių Biblioteka, Vilnius Fond 17 (Kolekcja), rkps, k. 6v. Dziennik podróży po Europie [Franciszek Bukaty]. 
Nacyânal'ny Gistaryčny Arhiǔ Belarusi, Minsk [Нацыянальны Гістарычны Архіў Беларусі, Мінск] Fond 694, op. 1, Archiwum Radziwiłłów, rkps 313. Korespondencja Radziwiłłów z Zawiszami. Fond 694, op. 1, Archiwum Radziwiłłów, rkps 337. Korespondencja Radziwiłłów z Potockimi. Fond 1324, op. 1, Archiwum Chmarów, rkps 43. Korespondencja Chmarów. Fond 1324, op. 1, Archiwum Chmarów, rkps 88. Korespondencja Chmarów. Fond 1636, op. 1, Archiwum Jeleńskich, rkps 123, k. 104. Korespondencja Jeleńskich. Fond 1727, op. 1, Księgi mińskie, rkps 14. Księgi mińskie (1765).

\section{ŹRÓDEA DRUKOWANE}

Dyjariusz podróży z Polski do Anglij z opisaniem wszelkich obserwacyi i ciekawości, które się mogly nadarzyć przejeżdżając przez różne miasta. W B. RoK. „Opis podróży przez Niemcy i Holandię do Londynu anonimowego szlachcica litewskiego z 1780 r.”. Śląski Kwartalnik Historyczny Sobótka 49, z. 3-4 (1994): 268-269.

Kitowicz, Jędrzej. Pamiętniki, czyli Historia polska, oprac. P. Matuszewska, kom. Z. Lewinówna. Warszawa: Państwowy Instytut Wydawniczy, 1971.

Krótki pamiętnik A. Hulewicza konfederata barskiego. W PUŁASKI, Kazimierz. Szkice i poszukiwania historyczne. Serya trzecia. Kraków: Spółka Wydawnicza Polska, 1906.

Niemcewicz, Julian Ursyn. Pamiętniki czasów moich, oprac. J. Dihm, t. I. Warszawa: Państwowy Instytut Wydawniczy, 1958.

„Notatki generała J.L. z lat 1775-1778. Ze starego rękopisu zebrane przez J.I. Kraszewskiego”. Biblioteka Warszawska 2 (1854): 413-528.

Pamiętnik do historyi polskiej w ostatnich latach panowania Augusta III i pierwszych Stanisława Poniatowskiego przez Adama Moszczy[e]ńskiego. Poznań: Księgarnia Jana Konstantego Żupańskiego, 1863 .

Pamiętniki Józefa Kossakowskiego biskupa inflanckiego 1738-1788, wyd. A. DAROWSKI. Warszawa: Księgarnia Gebethnera i Wolffa, 1891.

Sejmiki. Prawo uchwalone dnia 24 marca 1791, 37-39 [reprint, Kórnik: Polska Akademia Nauk, Biblioteka Kórnicka, 1985].

\section{OPRACOWANIA}

AdolPhowA, Krystyna. „Szlachta litewska wobec Zbioru Praw Andrzeja Zamoyskiego (w świetle litewskich instrukcji poselskich z lat 1776, 1778, 1780, 1782)". W Księga pamiatkowa Koła Historyków stuchaczy USB w Wilnie, 156-188. Wilno: Zrzeszenie Kół Naukowych Uniwersytetu Stefana Batorego, 1933.

AugustYNIAK, Urszula. „Granice wolności obywatela Rzeczypospolitej w XVI-XVII w. Jednostka wobec władzy, prawa i społeczeństwa”. W Wolność i jej granice. Polskie dylematy, red. J. Kloczkowski, 13-36. Kraków: Ośrodek Myśli Politycznej, Wyższa Szkoła Europejska im. ks. J. Tischnera, 2007.

BARTKIEWICZ, Kazimierz. Obraz dziejów ojczystych w świadomości historycznej w Polsce doby oświecenia. Poznań: Państwowe Wydawnictwo Naukowe, 1979.

BERNACKI, Włodzimierz. Myśl polityczna I Rzeczypospolitej. Kraków: Arcana, 2011.

BurszTA, Józef. Lud - naród - kultura. Z początków ludoznawstwa. W Naród. Kultura. Osobowość. Księga poświęcona Profesorowi Józefowi Chałasińskiemu, 39-49. Wrocław: Zakład Narodowy im. Ossolińskich, 1983. 
BUTTERwick, Richard. Polska rewolucja a kościót katolicki 1788-1792. Kraków: Arcana, 2012.

ChELIŃSKI, Stanisław. Organizacja państwa polskiego wedtug ustaw Sejmu Grodzieńskiego z r. 1793. Warszawa, 1918.

CZAJA, Aleksander. Między tronem, buława a dworem petersburskim. Z dziejów Rady Nieustającej 1786-1789. Warszawa: Państwowe Wydawnictwo Naukowe, 1988.

DANILCZYK, Adam. W kręgu afery Dogrumowej. Sejm 1786 roku. Warszawa: Neriton, 2010.

DukwiCz, Dorota. Rosja wobec sejmu rozbiorowego warszawskiego (1772-1775). Warszawa: Instytut Historii PAN, 2015.

FILIPCZAK, Witold. Sejm 1778 roku. Warszawa: Semper, 2000.

FILIPCZAK, Witold. Życie sejmikowe prowincji wielkopolskiej $w$ latach 1780-1786. Łódź: Wydawnictwo Uniwersytetu Łódzkiego, 2012.

GRABSKI, Andrzej Feliks. Myśl historyczna polskiego oświecenia. Warszawa: Państwowe Wydawnictwo Naukowe, 1976.

GrZeŚKowiAK-Krwawicz, Anna. „Przyszłam do Polski z Lechem... Konfederaci barscy a polska tradycja wolności”. W Konfederacja barska, jej konteksty i tradycje, red. A. Buchmann, A. Danilczyk, 237-254. Warszawa: Wydawnictwo DiG, 2010.

GrzeŚKowiaK-Krwawicz, Anna. Regina libertas. Wolność w polskiej myśli politycznej XVIII wie$k u$. Gdańsk: Wydawnictwo słowo/obraz terytoria, 2006.

GRZEŚKOWIAK-KRWAWICZ, Anna. „Wolność w propagandzie powstania kościuszkowskiego”. W Kościuszko - powstanie 1794 r. - tradycja. Materiaty z sesji naukowej w 200-lecie powstania kościuszkowskiego, 15-16 kwietnia 1994 r., red. J. Kowecki, 27-60. Warszawa: Biblioteka Narodowa, 1997.

KALENKIEwiczównA, Anna. „Rozkład partii Tyzenhauza na tle sejmików litewskich”. W Księga pamiątkowa Koła Historyków stuchaczy USB w Wilnie, 121-155. Wilno: Zrzeszenie Kół Naukowych Uniwersytetu Stefana Batorego, 1933.

KONOPCZYŃSKI, Władysław. Konfederacja barska, t. I. Warszawa: Volumen, 1991.

KościaŁKowski, Stanisław. Antoni Tyzenhauz, podskarbi nadworny litewski, t. I-II. Londyn: Wydawnictwo Społeczności Akademickiej Uniwersytetu Stefana Batorego w Londynie, 1971.

KurdybaCHA, Łukasz i Mitera-Dobrowolska Mieczysława. Komisja Edukacji Narodowej. Warszawa: Państwowe Wydawnictwo Naukowe, 1973.

LEŚNODORSKI, Bogusław. „Mowy Andrzeja Zamoyskiego na konwokacji 1764”. W Księga pamiątkowa 150-lecia Archiwum Głównego Akt Dawnych, 384-396. Warszawa: Państwowe Wydawnictwo Naukowe, 1958.

LIS, Rafał. W poszukiwaniu prawdziwej Rzeczypospolitej. Glówne nurty myśli politycznej Sejmu Czteroletniego. Kraków: Akademia Ignatianum, Wydawnictwo WAM, 2015.

ŁASZEWSKI, Ryszard. Sejm polski w latach 1764-1793. Studium historyczno-prawne. Warszawa-Poznań: Państwowe Wydawnictwo Naukowe, 1975.

ŁEPKOWSKI, Tadeusz. Polska - narodziny nowoczesnego narodu 1764-1870. Warszawa: Państwowe Wydawnictwo Naukowe, 1967.

Michalski, Jerzy. „Konarski Hieronim (Stanisław)”. W Polski słownik biograficzny, t. XIII, red. E. Rostworowski, 471-477. Wrocław-Warszawa-Kraków: Zakład Narodowy im. Ossolińskich, Wydawnictwo Polskiej Akademii Nauk, 1967-1968. 
MichalSKI, Jerzy. „O rzekomych i rzeczywistych pismach A. Zamoyskiego”. W J. Michalski. Studia Historyczne z XVIII i XIX wieku, t. I: Polityka i społeczeństwo. Warszawa: Stentor, 2007.

MichAlSki, Jerzy. „Plan Czartoryskich naprawy Rzeczypospolitej”. W J. Michalski. Studia Historyczne z XVIII i XIX wieku, t. I: Polityka i społeczeństwo. Warszawa: Stentor, 2007.

MiCHALSKI, Jerzy. „Radziwiłł Karol Stanisław”. W Polski słownik biograficzny, t. XXX, red. E. Rostworowski, 248-262. Wrocław-Warszawa-Kraków-Gdańsk-Lódź: Zakład Narodowy im. Ossolińskich, Wydawnictwo Polskiej Akademii Nauk, 1987.

MichALSKI, Jerzy. „Rejtan i dylematy Polaków w dobie pierwszego rozbioru”. W J. Michalski. Studia Historyczne z XVIII i XIX wieku, t. I: Polityka i społeczeństwo. Warszawa: Stentor, 2007.

MichALSKI, Jerzy. Schytek konfederacji barskiej. Wrocław: Zakład Narodowy im. Ossolińskich, 1970.

MichalsKi, Jerzy. „Sejm polski w czasach panowania Stanisława Augusta”. W Historia sejmu polskiego, red. J. Michalski, t. I. Warszawa: Państwowe Wydawnictwo Naukowe, 1984.

Pelcowa, Halina. „Wolność i niepodległość w systemie wartości mieszkańców wsi”. Rozprawy Komisji Językowej ŁTN 60 (2014): 219-233.

RoLNIK, Dariusz. Leonarda Marcina Świeykowskiego (1721-1793) ostatniego wojewody podolskiego życie codzienne i publiczne oraz jego myśli o Rzeczypospolitej. Katowice: Wydawnictwo Uniwersytetu Śląskiego, 2016.

RoLNIK, Dariusz. Portret szlachty czasów stanisławowskich, epoki kryzysu, odrodzenia i upadku Rzeczypospolitej w pamiętnikach polskich. Katowice: Wydawnictwo Uniwersytetu Śląskiego, 2009.

RoLNIK, Dariusz. „Sejmiki poselskie drugiej połowy panowania Stanisława Augusta (1778-1793). O czynnikach i motywacjach decydujących o wyborze posłów sejmowych". W Po unii- sejmiki szlacheckie w Rzeczypospolitej XVI-XVIII wieku, red. H. Lulewicz, M. Wagner, 331-355. Siedlce: Instytut Historii i Stosunków Międzynarodowych Uniwersytetu Przyrodniczo-Humanistycznego, 2013.

RoLNIK, Dariusz. „Społeczeństwo szlacheckie Rzeczypospolitej a wojsko w czasie Sejmu Czteroletniego i w okresie rządów konfederacji targowickiej (1788-1793)". W Społeczeństwo staropolskie. Seria nowa, t. IV, red. I.M. Dacka-Górzyńska, A. Karpiński, M. Nagielski, 309-334. Warszawa: Wydawnictwo DiG, 2015.

Rostworowski, Emanuel. „Moszczeński Adam”. W Polski słownik biograficzny, t. XXII, red. E. Rostworowski, 87-91. Wrocław-Warszawa-Kraków-Gdańsk-Łódź: Zakład Narodowy im. Ossolińskich, Wydawnictwo Polskiej Akademii Nauk, 1977.

RostworowsKi, Emanuel. „Z dziejów genezy konfederacji barskiej. Związek wojskowy Pułaskiego a dworski projekt reformy kawalerii". W Z dziejów wojny i polityki. Księga pamiątkowa ku uczczeniu siedemdziesiatej rocznicy urodzin Janusza Wolińskiego, red. K. Hanulak. Warszawa: Wojskowa Akademia Polityczna im. F. Dzierżyńskiego, Wydział Historyczno-Polityczny, 1964

RuDNICKI, Kazimierz. Biskup Kajetan Sołtyk 1715-1788. Kraków-Warszawa: W.L. Anczyc, 1906.

STASIAK, Arkadiusz Michał. Patriotyzm w myśli konfederatów barskich. Lublin: Towarzystwo Naukowe KUL, 2005.

STASIAK, Arkadiusz Michał. Teoria władzy monarszej czasów stanisławowskich. Studium idei. Lublin: Wydawnictwo KUL, 2013.

SZCZYGIELSKI, Wojciech. Referendum trzeciomajowe. Sejmiki lutowe 1792 roku. Łódź: Wydawnictwo Uniwersytetu Łódzkiego, 1994.

WĄSICKI, Jan. Konfederacja targowicka i ostatni sejm Rzeczypospolitej z 1793 roku (studium historyczno-prawne). Poznań: Poznańskie Towarzystwo Przyjaciół Nauk, 1952. 
ZAHORSKI, Andrzej. „Powstanie kościuszkowskie 1794”. W Trzy powstania narodowe, kościuszkowskie, listopadowe, styczniowe, red. W. Zajewski. Warszawa: Książka i Wiedza, 2000.

ZieliŃSKA, Zofia. „O sukcesyi tronu w Polszcze” 1787-1790. Warszawa: Wydawnictwo Naukowe PWN, 1991.

ZIELIŃSKA, Zofia. „Sejmiki 8 lutego 1790. Pierwsze referendum na temat dokonań sejmu”. Wiek Oświecenia 9 (1993): 113-137.

ZIELIŃSKA, Zofia. „Stanisław August wobec konfederacji i konfederatów barskich”. W Konfederacja barska jej konteksty i tradycje, red. A. Buchmann, A. Danilczyk, 117-130. Warszawa: Wydawnictwo DiG, 2010.

ŻEREK-KLESZCZ, Hanka. „Michał Walewski podkomorzy krakowski i wojewoda sieradzki i jego korespondencja z królem Stanisławem Augustem 1777-1787”. Rocznik Łódzki 48 (2001): 47-65.

ŻEREK-KLESZCZ, Hanka. „Nominacje senatorskie Stanisława Augusta Poniatowskiego w okresie Rady Nieustającej”. Przeglad Nauk Historycznych 5, nr 1 (2006): 209-233.

\section{IDEA PAŃSTWA WOLNEGO, SUWERENNEGO I NIEPODLEGEEGO - FENOMEN PRZEMIAN CZASÓW SEJMU CZTEROLETNIEGO?}

\section{Streszczenie}

Czasy stanisławowskie przyniosły refleksję obywateli nad istotą Rzeczypospolitej, ta zaś doprowadziła do próby jej reformowania w czasach Sejmu Wielkiego. Proces ten w swej warstwie powierzchniowej jest znany, jednak jak dokładnie on przebiegał, nie wiemy. Z pewnością tym, co skłaniało współczesnych do refleksji, były nieszczęścia, które spadły na państwo polsko--litewskie. Można je różnie definiować i wskazywać na większą lub mniejszą rolę w tym procesie „odradzania narodu”. Aby jednak zmiana nastąpiła, musiało dojść do upowszechnienia takiego toku myślenia i to zagadnienie wydaje się kluczowe do tego, by zrozumieć istotę czasów stanisławowskich. Można zgodzić się $\mathrm{z}$ tezą, że zaczyn dobrego zrodził się w głowach ówczesnych elit, w tym również Stanisława Augusta. Jednak idee naprawy państwa, by mogły się zmaterializować, musiała przejąć inna siła, wydaje się, że była nią średnia szlachta. To oczywiście hipoteza i jej potwierdzenie wymaga jeszcze wielu badań, ale wiele wskazuje, że to ona doprowadziła nie tyle do uchwalenia Konstytucji 3 maja, ile do sytuacji, w której większość narodu szlacheckiego była gotowa ją zaakceptować. Sugeruję, że zdecydowała o tym zmiana myślenia elit szlacheckich o roli państwa, czemu towarzyszyła przemiana hierarchii wartości wewnętrznych ważnych w życiu społeczeństwa (co bynajmniej nie oznaczało porzucenia idei republikańskich). Ta ostatnia kwestia jest trudna do definiowania, w sferze tej źródła mają bardzo często charakter deklaratywny - np. wartość przysiąg, oświadczenia poświęcenia dla ojczyzny - trzeba je więc konfrontować z konkretnymi zachowaniami obywateli i dopiero na podstawie otrzymanych wyników starać się o ogólniejsze wnioski.

Słowa kluczowe: Sejm Wielki; reformy czasów stanisławowskich; państwo - obywatel w Rzeczypospolitej XVIII w.; elity stanisławowskie; stronnictwa polityczne. 


\section{THE IDEA OF A FREE, SOVEREIGN AND INDEPENDENT STATE - A PHENOMENON OF THE CHANGE OF TIMES OF THE FOUR-YEAR SEJM?}

\section{S u m m ary}

The Stanislaus times brought citizens' reflection on the essence of the Republic. This reflection led to an attempt to reform the state in the times of the Great Sejm. This process in its surface layer we know, but we do not understand how exactly it proceeded. Indeed, what prompted the contemporaries to reflect was the misfortunes that affected the Polish-Lithuanian state. These misfortunes - defined differently - played a greater or lesser role in this process of "rebirth of the nation." For this change to occur, it had to be made more widely thought about the causes of the country's weakness. This issue seems crucial in order to understand the essence of the Stanislaus times and their reforms. One can agree with the thesis that this process was started by the elites of the time, including Stanislaw August. However, the ideas of repairing the state to materialize had to find more substantial support, which proved to be the average nobility. This hypothesis, its confirmation, still requires much research. However, many indicate that it led, not so much to the acceptance of the 3 May Constitution but to a situation in which most noble people were ready to accept it. This was decided by a change in the thinking of the noble's elites about the state's role, which was accompanied by a change in the hierarchy of internal values, significant in society's life (which by no means meant abandoning republican ideas). The latter issue is challenging to define, and in this area, the sources are very often declarative - e.g. the value of oaths, declarations of sacrifice for the homeland.

Keywords: Grand Sejm; reforms of the Stanislaus era; state - citizen in the Republic of the 18th century; Stanislaus' elites; political parties. 